\title{
Medushevsky a law and public ethics: constitution of internet in e-government formation (reflections on international debates)
}

\section{Proceeding}

The general Internet-Constitution debate reveals three predominant interpretations of e-government phenomenon: e-government as a principally new form of government which already strayed beyond bureaucracy realizing the Antic ideal of direct democracy; ${ }^{1-2}$ e-government as a new technical tool which could be appropriate and used by different actors and by the traditional bureaucratic government among them ${ }^{3-10}$ and e-government as the dangerous way toward a new type of bureaucratic control over society - the new Leviathan. ${ }^{11-13}$ All three interpretations are based on technological aspects of the problem - the evaluation of the role and impact of e-government machinery on social structure, the reconfiguration of social roles in the traditional hierarchy of governance. The phenomenon of overestimation of e-government innovations explains the search of easy answers and the expansion of the simplified (populist) visions of the future government - the "false sense of transparency and accountability". The contemporary e-government project is not a solution to problems related to democracy but rather the challenge to it which put under question the principle of legality by transmuting governmental discretionary power out of the politically controllable sphere to new one system e-bureaucracy designers. E-government does not imply the weakening of the traditional state but rather new forms and methods of administration. This phenomenon could be reinterpreted in the categories of ethics, philosophy of law and political science.

The actual debate over Internet-Constitution assesses the state of e-government and provides an alternative path for the development of e-government. The new approach argues that previous conceptions of e-government are limited through their focus on technology, and that this focus in turn engenders social, politico-technical and legal problems. Throughout the debate, it raises numerous issues from an apparent decline in 'state prestige' to efficiency and authoritarianism, whilst grounding these in a multidisciplinary background of theory. The author proposes a new approach oriented instead on the conception of information, its exchange, and its formalization. The method of this research is cognitive information constructivism; the subject is the reconstruction of ethical prerequisites of formal and informal frameworks for e-government and the goal - is the redefinition of the e-government strategy priorities.

Any living law constitutes simultaneously certain values, a system of regulatory authority, and a mechanism to implement that authority. Further, in order for the law to function effectively it has to be legitimate i.e. it must be fair in the eyes of the public. This requires that first the aims (or goals) behind law conform with the sense of public morality; second, that it be implemented in an impartial manner; and, thirdly, that it be applied efficiently by the judicial system. ${ }^{14-16}$ In reality, however, and especially in the case of IT-relations, the mutual coexistence of these three components has proven to be elusive. The legal principles established to regulate information exchanges are not always regarded by the public as either optimal or legitimate. The
Volume 6 Issue 5 - 2018

\author{
Andrey N Medushevsky \\ Doctor of sciences (Philosophy), Tenured professor at the \\ National Research University, Russia
}

Correspondence: Andrey N Medushevsky-doctor of sciences (Philosophy), Tenured professor at the National Research University Higher School of Economics, Moscow, Russia, Email amedushavsky@mail.ru

Received: November 12, 2017 | Published: November 02, 2018

transubstantiation of these principles into legal provisions has been incomplete, plagued by ambiguity and inconsistency. The substance of law has been the subject of continual change. Finally, even where it has been possible to adequately obtain a correlation between the first two components, the effective application of the law by the judiciary has remained unreachable, a result of both the instability of the law and the contradictions arising in its consequent interpretation, and the very weaknesses of the judiciary itself in comparison with executive authority.

In concentrated form these lines of argumentations are represented in the current discussion on such acute questions as the InternetConstitution as well as the ethical codices for different parts of the Internet-community in the area of internet rights and human rights protection in general. ${ }^{17-18}$ The growing importance of international law and the role of the meta-constitutional regulations reveal the diminishing role of national governments in the process of the global e-government establishment. ${ }^{19-23}$ The main prerequisites of sustainable Internet-Constitution apparently involves such criteria as a common understanding the term "information" as a category for operative administrative processes, the uncontroversial legal regulation of production, use, verification of information for the ends of governance, the elaboration of the soft-law or ethical codices in key areas of administration, ${ }^{24-27}$ the independent international monitoring of all national initiatives in this area, the internationally based group of professional analysts capable to preview social consequences of new technical innovations. ${ }^{28-31}$

There is a lack of consensus over which strategy should be used to overcome the aforementioned difficulties. Some lawyers assume that the gaps, omissions and contradictions of legislation ought to be overcome through the adoption of the international InternetConstitution, new state laws, codes and even the establishment of new branches of law. Others believe that the existing basic laws are sufficient, and only amendments to them are required, an argument consistent with the idea of the importance of maintaining legal stability. Finally, a third view asserts that the solution will be provided through the interpretation of current law and the development of judicial 
practices. The creation of independent cross-national expertise pool is thus important for the elaboration of new regulations in e-government area as well as for the selection and professional criticism of various national laws and recommendations.

The priority to flexible juridical regulation instead of the rigid one is the reflection of uncertainties in three major aspects of e-government articulation:

a. Different theoretical interpretations of this phenomenon (as a sustainable new form of the deliberative democracy or pure technical innovation);

b. The gap between positive law prescriptions and dynamic process of the technical transformation (upheaval modernization of law after the revolutionary technological changes);

c. The collision between main stakeholders about the mechanisms of e-government regulations (spontaneous self-regulation or norms, imposed from above by the state bureaucracy). ${ }^{32}$

The author considers the ethical values and standards as one of the mostly effective ways for possible progress in this field of public life. They could be introduced by changes in the prevailing political and administrative culture of society and by the implementation of cognitive methods of social regulation, based on new ITcommunications and e-government idea. The problem of divorce between fairness and efficiency, politics and morality, bureaucratic ethic and democracy could be reconsidered on the basis of the current international debates on the Internet-Constitution and its prospects. ${ }^{33}$

It is this very lack of a system that encourages the deployment of such a 'sociological' approach. To understand decision making processes in the field of public ethics, legal policy and e-government regulation it is important to understand the factors that promote, restrict, and distort the processes. This in turn requires an analysis of the failure to establish in the behaviour of institutions and individuals such values as ethics in the public IT-policy as factors for sociocultural changes, the respect for e-government legal regulation and procedures standards, and an acknowledgement of the decisions of courts as dispute resolution mechanisms. This strategy presumably provides the possibility to offer a prognostic approach, involving an analysis of the correlation between the beliefs, norms and reality, and based on previous experience of e-government regulation in national and comparative perspective.

\section{Acknowledgement}

None.

\section{Conflict of interest}

The author declares that there is no conflict of interest

\section{References}

1. Fontaine J. Building the Virtual State: Information Technology and Institutional Change. Brookings institution press; 2001.

2. Fountain J. The Virtual State: Transforming American Government? National Civic Review. 2001;90(3):241.

3. Kahin B, Keller J. Coordinating the Internet. Cambridge (Mass): University press; 2000.
4. Garson GD. Public Information Technologies and E-Government: Managing the Virtual State. 2006.

5. Bekkers V, Vincent H. The Myths of E-Government: Looking Beyond the Assumptions of a New and Better Government. The Information Society. 2007:23(5):373-382.

6. Calista DJ, Melitski J. E-Government and E-Governance: Converging Constructs of Public Sector Information and Communication Technologies. Public Administration Quarterly. 2007:31(1-2):87-120.

7. Budd L, Harris L. E-governance: Managing or Governing? New York: Routledge; 2009.

8. Nixon GP, Koutrakon VN, Raval R. Understanding E-Government in Europe. London and New-York, Routledge. 2010.

9. Mutula S, Mostert J. Challenges and Opportunities of E-Government in South Africa. The Electronic Library. 2010;28(1):38-53.

10. Bradshaw S, Harris K. Governing the Internet: Chaos. Control or Consensus? 2013.

11. Ronfeldt D. Cyberocracy is coming. The Information Society, 1992;8(4):243-296.

12. Ronfeldt D, Varda D. The Prospects of Cyberocracy (Revisited). 2008.

13. Meier P. The prospects of Cyberocracy. Comments. 2009.

14. Macintyre A. After Virtue. London: Univ of Notre Dame Press; 1984.

15. Dam KW. The Law-Growth Nexus. The Rule of Law and Economic Development. 2006.

16. Sandel MJ. Justice: What's the Right thing to do? London: Penguin books; 2010.

17. Mckeown M. The Internet and the Constitution: A selective Retrospective. Washington Journal of Law, Technology \& Arts. 2014;9(3)

18. Internet Legislation and Regulation through the Eyes of the Constitution Exploring Alexander von Humboldt Institut fur Internet und Gesellschaft. Workshop Conference Papers. 2015.

19. Rodota S. A Constitution for the Internet. Federalist debate. 2006:19(1).

20. Takala R. Lawmakers: US Plan for Internet may be Unconstitutional. Washington examiner. 2015.

21. Brazil Close to its own "Constitution for the Internet". 2014.

22. Abramovay P. Brazil's Statute of Virtual Liberty. ProjectSyndicate. 2014.

23. Toobin A. Edward Snowden is writing a Constitution for the Internet. Inverse. 2016.

24. Abbott K, Snidal D. Hard and Soft Law in International Governance. International Organization. 2000;54(3):423.

25. Lemley M, Menell P, Merges R, et al. Introduction to Computer Technology. Network Economics and Intellectual Property. 2006. 
26. Software and Internet Law. Aspen Law \& Business. 2006.

27. Hindeland S. Refocusing on the Constitution-Approaching Internet Legislation and Regulation through the Eyes of the Constitution. A Reseach Sketch. In: Alexander von Humboldt Institut fur Internet und Gesellschaft. 2015.

28. Elizabeth Lupfer. The Ethos of the Internet and a Culture of Innovation. 2011

29. The Internet Ethos. 2014.
30. Dublin University Internet Society Constitution. 2016.

31. Develop an Internet Constitution. 2016.

32. Improve ICANNS Transparency and Accountability. 2016.

33. Medushevsky AN. Terrorism and the State: Limits of SelfProtection (The Parameters of Internet (RUNET) Regulation. Cardozo Law Review. 2007;29(1):21-23. 